\title{
ENERGY CONSUMPTION, ECONOMIC GROWTH AND GREENHOUSE GAS EMISSIONS IN THE EUROPEAN UNION COUNTRIES
}

\section{Giedrè LAPINSKIENE் ${ }^{1}$, Kęstutis PELECKIS ${ }^{2}$, Neringa SLAVINSKAITE் 3}

Vilnius Gediminas Technical University, Sauletekio al. 11, LT-10223 Vilnius, Lithuania E-mails: ${ }^{1}$ giedre.lapinskiene@vgtu.lt (correspondingauthor); ${ }^{2}$ kestutis.peleckis@vgtu.lt;

$3_{\text {neringa.slavinskaite@vgtu.lt }}$

Received 01 June 2017; accepted 13 October 2017

\begin{abstract}
This paper investigates the relationship between economic growth, greenhouse gas emissions and other factors based on the panel data of 22 countries of the EU in the period 1995-2014. The fixed effect panel model was used as a framework for the analysis. The novel contribution of this paper is that the factors of economic growth, energy consumption, energy taxes as well as R\&D were tested in one expanded EKC model, including the data of three Baltic States. The regression coefficients referring to GDP, Energy consumption have a positive sign, while R\&D and Energy taxes have a negative sign. The empirical analysis combines two steps of evaluation of panel models of different groups of countries. The results imply that the analysed factors (energy consumption, energy taxes as well as R\&D) can be applied to adjust the EKC trend in the region and might be useful for the climate change policy adjustment.
\end{abstract}

Keywords: greenhouse gases, energy consumption, gross domestic product, environmental Kuznets curve, European Union countries, fixed effect panel model.

JEL Classification: Q56, C33.

\section{Introduction}

The European Union stated that the prevention of climate change is one of the strategic priorities and encouraged other countries to follow its example. The European Union claimed the reduction of greenhouse gas emissions by at least $20 \%$ compared to the levels of 1990 till 2020, then $40-60 \%$ till 2040 and $80 \%$ till 2050 to be one of its strategic priorities (Europe 2020). In the scientific world, the question if the economic growth harms the environment has been widely discussed by environmental economists for a long time. The theoretical considerations of the relationship between the environment and economic growth starts, in many cases, with presenting the famous book "The Limits to Growth" (Meadows et al. 1972) inspired by the informal organization The Club of Rome. It was noticed that the rates of such variables as population growth, usage of resources, level of pollution and material consumption grew according to the trajectory of the exponential function. In 2012, Randers, one of the authors of "The Limits to 
Growth", published another book, where he forecasts the future pessimistically (Randers 2012). The latest studies of the environmental degradation and growth are related to the hypothetical Kuznets curve approach. The environmental Kuznets curve (EKC) is a hypothetical relationship between various indicators of environmental degradation and income level, referring to the shape of the inverted-U. The environmental Kuznets curve appeared to be in the centre of this discussion after the publication of seminal works of Grossman and Krueger (Grossman, Krueger 1991, 1995). In the first stream of EKC studies, reduced EKC models have been estimated without any additional explanatory variables except for GDP proxy variables (Grossman, Krueger 1991, 1995; Shafik, Bandyopadhyay 1992; Selden, Song 1994; Holtz-Eakin, Selden 1995). In the later EKC studies, so-called "expanded EKC models" (the expanded model includes some additional factors based on the economic logic and data availability) were used, where the relationship between environmental quality indicators and a broader set of economic development variables: energy consumption, trade openness, urbanization and others were tested (Iwata et al. 2011; Baodong, Xiaokun 2011; Esteve, Tamarit 2012; He, Wang 2012; Fujii, Managi 2013; Liao, Cao 2013; Lin, Liscow 2013; Onafowora, Owoye 2014; Lapinskienė et al. 2013, 2014, 2017; Ginevičius et al. 2017). The higher economic growth requires more energy consumption and more efficient energy use needs a higher level of economic growth. In latest studies the energy sector is defined as the most robust determinant of greenhouse gas emissions (GHG) emission. This group of researchers used various indicators to evaluate the importance of energy sectors. A survey of the existing literature can be divide into three groups: GHG $\left(\mathrm{CO}_{2}\right)$ - GDP - general energy consumption, GHG $\left(\mathrm{CO}_{2}\right)$ - GDP - energy consumption by different sources as well as GHG $\left(\mathrm{CO}_{2}\right)$ - GDP - general energy consumption by sectors. This study contributed to the first group of studies. The majority of the studies limit their analysis by only linking the total energy consumption and economic growth to environmental pollution, particularly $\mathrm{CO}_{2}$ emissions (Marrero 2010; Baek 2015), others include additional variables as trade, foreign investment etc. in order to explain the analysed relationship. The study provides a new empirical research on the expanded EKC model for twenty European countries in the period 1995-2014. To the best of our knowledge, so far there has been no study that tests the EKC hypothesis for such a sample of countries, specially capturing the three Baltic States. To provide other perspective, the main objective of this study is to test the robustness of additional factors like energy consumption, research and development and energy taxes into one model. The 21-st century is the age of the biology science and the novelties in this field may lead to higher prosperity and cleaner environment. It is assumed that improving technologies will lead to better environment without limiting general growth trends. The EU has increasingly favoured environmental taxes as instruments because they provide a flexible and cost-effective means for reinforcing the polluter-pays principle and for reaching environmental policy objectives. The intensity of energy consumption reflects the carbon intensity of each economy. The second objective to check if countries which are more developed, i.e. has higher GDP per capita, uses resources more productivly, if that is true we expect coefficient in front of energy consumption to be smaller. 
The paper has the following structure. Sections 1 and 2 provide important theoretical and econometrical issues based on the considered concepts. Section 3 describes the main findings of the research. The last section summarizes the results, providing the concluding remarks and defining possible areas for further research.

\section{Literature review and modelling framework}

The latest EKC studies combine the relationship between environmental pollution and economic growth and some other variables. To empirically analyse whether or not additional factors are important researchers have expanded the quadratic and cubic equations by adding some additional variables. Based on the empirical studies, general theoretical causes and factors affecting the relationship between the environment indicators and economic activity might be divided into several topics: scale of economic activity; the structure of economy; technological development, international trade and the pollution haven hypothesis, income inequality of income distribution; political-governance factors; social-demographical factors; historical events or shocks; country-specific factors. The empirical investigations of factors, affecting $\mathrm{GHG}$ or $\mathrm{CO}_{2}$ as the main indicators referring climate change, shows that researcher used various indicators assessing the significance of special social-economic factors. The executed systemic analysis of empirical studies, where the EKC analysis was extended to include some additional variables, has led to the notion, that different locations and different time series may be significantly impacted by special factors. The scale of economic activity, composition of economy and technological development are impacting the environment through the economic growth and are often mentioned by researchers as the main ones. Manager's values, environmental and economic attitudes, for improving enterprises environmental responsiveness, can also be seen as important factors for improving and managing way toward more sustainable society (Potocan et al. 2016; Lapinskienè et al. 2017). The main source of GHG is related to energy consumption, especially the high share of electricity production from coal and oil sources in the total electricity production, while high divergence in GHG amounts remains even among separate EU countries. It means that the intensity of energy consumption reflects the carbon intensity of each economy. The countries with dominant energy intensive sectors such as energy and business, release more GHG compared to the countries, importing more energy intensive products like those made of iron and steel. A countries' endowment of resources impacts the energy mix proportion: for example, a relatively high propensity to use coal in Poland and Estonia clearly impacts the level of greenhouse gas emissions per capita. The type of the consumed resources can explain the differences.

Studies given in Table 1 investigate the relationship between $\mathrm{GHG} \mathrm{CO}_{2}$ emissions as a proxy for pollution, GDP (or economic growth) and aggregate energy (electricity) consumption. 
Table 1. GHG $\left(\mathrm{CO}_{2}\right)$ - GDP - general energy consumption

\begin{tabular}{lccll}
\hline Author/Year & $\begin{array}{c}\text { Periodo of } \\
\text { study }\end{array}$ & $\begin{array}{c}\text { Country/ } \\
\text { region }\end{array}$ & \multicolumn{1}{c}{ Methods } & \multicolumn{1}{c}{ Results } \\
\hline $\begin{array}{l}\text { Marrero } \\
(2010)\end{array}$ & $1990-2006$ & Europe (27) & $\begin{array}{l}\text { Panel ordinary least } \\
\text { squares fixed effect and } \\
\text { generalized methods of } \\
\text { moments model }\end{array}$ & $\begin{array}{l}\text { Energy consumption } \\
\text { and GDP growth have } \\
\text { a positive effect on } \mathrm{CO}_{2} \\
\text { emission in most of the } \\
\text { models }\end{array}$ \\
\hline
\end{tabular}

\begin{tabular}{|c|c|c|c|c|}
\hline $\begin{array}{l}\text { Al-Mulali } \\
\text { et al. }(2015)\end{array}$ & $1980-2008$ & 93 countries & $\begin{array}{l}\text { Panel ordinary least } \\
\text { squares fixed effect and } \\
\text { generalized methods of } \\
\text { moments model, Ime- } \\
\text { Pesarane-Shin unit root, } \\
\text { Augmented Dickeye } \\
\text { Fuller unit root and } \\
\text { Phillipse Perron unit root } \\
\text { tests. }\end{array}$ & $\begin{array}{l}\text { Energy consumption, } \\
\text { trade openness and } \\
\text { urbanization contribute } \\
\text { to } \mathrm{CO}_{2} \text {; financial } \\
\text { development mitigates } \\
\mathrm{CO}_{2}\end{array}$ \\
\hline Atici (2009) & 1980-2002 & $\begin{array}{l}\text { Central and } \\
\text { Eastern } \\
\text { Europe }\end{array}$ & $\begin{array}{l}\text { Panel ordinary least } \\
\text { squares fixed effect model }\end{array}$ & $\begin{array}{l}\text { Energy consumption } \\
\text { contributes to } \mathrm{CO}_{2} \text {, trade } \\
\text { openness is insignificant }\end{array}$ \\
\hline $\begin{array}{l}\text { Ozturk and } \\
\text { Acaravci } \\
(2010)\end{array}$ & $1980-2006$ & $\begin{array}{l}\text { Albania, } \\
\text { Bulgaria, } \\
\text { Hungary, } \\
\text { Romania }\end{array}$ & $\begin{array}{l}\text { Time series, autoregressive } \\
\text { distributed lag model, } \\
\text { vector error correction } \\
\text { mechanism causality }\end{array}$ & $\begin{array}{l}\text { Albania, Bulgaria, } \\
\text { Romania: no causality; } \\
\text { Hungary: Energy } \\
\text { Consumption mitigates } \\
\mathrm{CO}_{2} \text {. }\end{array}$ \\
\hline
\end{tabular}

\begin{tabular}{|c|c|c|c|c|}
\hline $\begin{array}{l}\text { Ajmi et al. } \\
(2015)\end{array}$ & $1960-2010$ & $\begin{array}{l}\text { G-7 } \\
\text { Countries }\end{array}$ & $\begin{array}{l}\text { Time series, augmented } \\
\text { Dickeye Fuller unit root, } \\
\text { Ng-Perron, time-varying } \\
\text { Granger } \\
\text { causality tests }\end{array}$ & $\begin{array}{l}\text { Energy consumption } \\
\text { contribute to } \mathrm{CO}_{2} \\
\text { (Japan, Italy, Canada, } \\
\text { USA, France) }\end{array}$ \\
\hline $\begin{array}{l}\text { Kasman and } \\
\text { Duman (2015) }\end{array}$ & 1992-2010 & $\begin{array}{l}\text { EU Countries } \\
\text { (new EU } \\
\text { member and } \\
\text { candidate } \\
\text { countries) }\end{array}$ & $\begin{array}{l}\text { Panel fully modified } \\
\text { ordinary least squares } \\
\text { model, } \\
\text { Ime Pesarane Shin unit } \\
\text { root, Breitung, Hadri, } \\
\text { Pedroni } \\
\text { cointegration, Granger } \\
\text { causality tests. }\end{array}$ & $\begin{array}{l}\text { Energy consumption, } \\
\text { trade openness and } \\
\text { urbanization contribute } \\
\text { to } \mathrm{CO}_{2}\end{array}$ \\
\hline $\begin{array}{l}\text { Shahbaz et al } \\
\text { (2015) }\end{array}$ & $1975-2012$ & $\begin{array}{l}99 \text { countries } \\
\text { (high-, } \\
\text { middle-, and } \\
\text { low-income } \\
\text { countries) }\end{array}$ & $\begin{array}{l}\text { Panel fully modified } \\
\text { ordinary least squares } \\
\text { model, Ime Pesarane } \\
\text { Shin unit root, Pedroni } \\
\text { cointegration, Johansen } \\
\text { cointegration tests. }\end{array}$ & $\begin{array}{l}\text { Energy consumption } \\
\text { and GDP contribute } \\
\text { to } \mathrm{CO}_{2} \text {, higher financial } \\
\text { development mitigate } \\
\mathrm{CO}_{2} ;\end{array}$ \\
\hline
\end{tabular}


End of Table 1

\begin{tabular}{|c|c|c|c|c|}
\hline Author/Year & $\begin{array}{c}\text { Periodo of } \\
\text { study }\end{array}$ & $\begin{array}{l}\text { Country/ } \\
\text { region }\end{array}$ & Methods & Results \\
\hline Baek (2015) & $\begin{array}{l}1990 \\
-2011\end{array}$ & $\begin{array}{l}\text { Canada, } \\
\text { Denmark, } \\
\text { Iceland, } \\
\text { Finland, } \\
\text { Norway, } \\
\text { Sweden, } \\
\text { USA }\end{array}$ & $\begin{array}{l}\text { Panel autoregressive } \\
\text { distributed lag model, } \\
\text { Dickeye Fuller test in } \\
\text { generalized least squares }\end{array}$ & $\begin{array}{l}\text { Energy consumption } \\
\text { contributes to } \mathrm{CO}_{2} ; \mathrm{GDP} \\
\text { mitigate } \mathrm{CO}_{2} \text { in some } \\
\text { countries }\end{array}$ \\
\hline $\begin{array}{l}\text { Al-mulali } \\
(2015)\end{array}$ & $\begin{array}{l}1980 \\
-2008\end{array}$ & $\begin{array}{l}93 \text { countries } \\
\text { (categorized } \\
\text { by income) }\end{array}$ & $\begin{array}{l}\text { Panel ordinary least } \\
\text { squares fixed effect and } \\
\text { generalized methods of } \\
\text { moments model, Ime } \\
\text { Pesarane Shin unit root, } \\
\text { Augmented Dickeye } \\
\text { Fuller unit root } \\
\text { tests }\end{array}$ & $\begin{array}{l}\text { Energy consumption, } \\
\text { trade openness and } \\
\text { urbanisation contribute } \\
\text { to } \mathrm{CO}_{2} \text {; financial } \\
\text { development mitigates } \\
\mathrm{CO}_{2}\end{array}$ \\
\hline
\end{tabular}

A large number of studies have concluded that energy consumption, GDP growth and GHG $\left(\mathrm{CO}_{2}\right)$ emissions are co-integrated. 78 percents of analysed studies used panel data, including samples of various sizes, starting from six countries (Baek 2015) to those covering thirty two countries (Al-mulali 2015). Time series analysis was performed in the Albania, Bulgaria, Hungary, Romania as well as G-7 countries. Most of researchers included additional factors (trade openness, urbanization, and financial development) to test in their models. Energy consumption, trade openness and urbanisation contribute to increase in emissions, financial development mitigates $\mathrm{CO}_{2}$. The most common model was panel ordinary least squares fixed effect model and time series autoregressive distributed lag model. The ecometrical models have been supported by various statistical tests (Ime-Pesarane-Shin unit root, Augmented Dickeye Fuller unit root, Phillipse Perron unit, Granger causality, Pedroni cointegration, Dickeye Fuller) in order to prove the robustness of the empirical results. According to Table 1, it is clear that the results from the previous studies focused on particular factors - total energy consumption, urbanisation, trade and financial development.

In this paper the factors economic growth, energy consumption, energy taxes as well as $\mathrm{R} \& \mathrm{D}$ were tested into one expanded EKC model in order to evaluate the relationship between economic growth and chosen factors. European countries are trying to reduce pollution by employing various tools such as the development of new energy consumption reduction technologies, emphasizing environmental $\mathrm{R} \& \mathrm{D}$ and approving new $\mathrm{CO}_{2}$ emissions rules. In the sustainable development, it is assumed that the largest part of $\mathrm{R} \& \mathrm{D}$ expenditure in theory might be related to the environmental friendly solutions. On the other hand, chosen model estimates various countries representing different starting points of $R \& D$ expenditure and the results might not be obvious. It should be noted that real investments in R\&D may show a substantial lag between the investment time and a positive result, while the statistical impact might not be caught from the past data. 
Despite these doubts, it is expected to have a negative sign of the coefficient by R\&D. Measures representing the environmental policy options are reflected by energy and environmental taxes. Taxes represent a classical and potentially reliable instrument of the environmental policy, used for reducing the harm of human activities on the environment. This research does not go deeper in the discussion about the effectiveness of these instruments. It is assumed that higher taxes might reduce the level of GHG and it is expected to have negative signs of coefficients representing energy taxes. Energy taxes are one of the factors affecting the market mechanism forces playing out in EKC analysis and which can be actively managed by policy makers.

Following the analysed literature and the modelling framework, the hypothesis was raised that all the selected variables have a statistically significant impact and economically expected relationship to GHG as presented in Table 2.

Table 2. Chosen proxy variables affecting EKC

\begin{tabular}{llll}
\hline \multicolumn{1}{c}{$\begin{array}{c}\text { Proxy } \\
\text { Variables }\end{array}$} & \multicolumn{1}{c}{ Description of a Proxy Variable } & $\begin{array}{c}\text { Eviews Code } \\
\text { (Annex 1) }\end{array}$ & $\begin{array}{c}\text { Expected } \\
\text { sign }\end{array}$ \\
\hline GHG & $\begin{array}{l}\text { This indicator shows trends in total man-made } \\
\text { emissions of the 'Kyoto basket' of greenhouse gases. It } \\
\text { presents annual total emissions in relation to emissions } \\
\text { in the Kyoto base year (1995) }\end{array}$ & GGEKY95 & \\
& GDP in PPS (Euro per capita) & GDP & Positive \\
\hline $\begin{array}{llll}\text { GDP per } \\
\text { Capita }\end{array}$ & $\begin{array}{l}\text { Research and experimental development include all } \\
\text { expenditures within the enterprise business sector } \\
\text { on the national territory during a given period and is } \\
\text { shown as a percentage of GDP }\end{array}$ & RD & Negative \\
\hline R\&D & $\begin{array}{l}\text { Ratio of energy tax revenues to the final energy } \\
\text { consumption (Euro per tonne) }\end{array}$ & ENERGTAX & Negative \\
\hline Energy taxes & $\begin{array}{l}\text { Gross inland consumption (TOE (tonnes of oil } \\
\text { equivalent)/per capita) Gross inland consumption is } \\
\text { calculated as follows: primary production + recovered } \\
\text { products + total imports + variations of stocks - total } \\
\text { exports - bunkers. }\end{array}$ & ENCONS & Positive \\
\hline $\begin{array}{l}\text { Energy } \\
\text { consumption }\end{array}$ & & \\
\hline
\end{tabular}

Source: created by authors.

In order to test the statistical significance of these variables and to prove the hypothesis raised, the expanded quadratic EKC equation was used for the estimation. The selected model for this step of the research is given below:

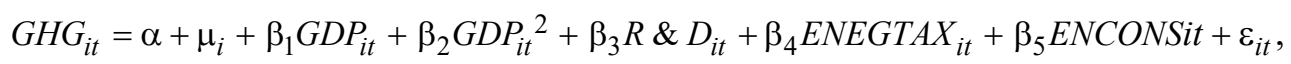

where $G H G_{i t}$ is a dependent variable for the country $i$ in the time $t ; G D P_{i t}, R \& D_{i t}$, ENERTAX $X_{i t}, E N C O N S_{i t}$ are the independent variables for the country $i$ in the time $t$; $\beta$ denotes the regression coefficients; $\mu_{i}$ is the cross-section specific effect; $\varepsilon_{i t}$ is an error term. 
The study employs the equation form used by Holtz-Eakin and Selden (1995), Wang et al. (2011), He and Wang (2012), Fujii and Managi (2013), and Boluk and Mert (2014). The study follows the panel data analysis performed by Marrero (2010), Boluk and Mert (2014), and Lopez-Menendez et al. (2014).

\section{Empirical analysis}

The empirical analysis combines two steps of evaluation of panel models of different groups of countries. In the first step, twenty two European states (Table 3) were considered to determine the expanded EKC model relationship between GHG and GDP as well as chosen factors. In this study, Bulgaria, Romania and Croatia were not included, as these countries joined the European Union only recently (2007 and 2013); therefore, these countries had a short period for the implementation of the European Union policies. Luxemburg, Cyprus and Malta were not analysed either because their population is less than 1 million, which may distort calculations of per capita terms. At the second stage, the chosen sample was divided into two groups based on the geographical region of the countries and the level of their development. By subdivision of the overall sample into two groups we aim for two insights. First we would like to check if countries which are more developed, i.e. has higher GDP per capita, uses resources more effectively, if that is true we expect coefficient in front of ENCONSUM to be statistically significantly smaller. Second we aim to check if graphical form of EKC is different for these two country groups. For this task we will check if coefficients in front of GDP and GDP2 are different.

The overall sample of 22 countries was subdivided into two groups (Table 3), where less developed countries were defined as countries which GDP per capita (in PPS) at the beginning of the period was less than 16000 PPS/capita and developed countries which GDP per capita above 16000 PPS. Italy was arbitrary moved to less developed country group due to its geographical/cultural proximity to remaining south European country block.

The empirical study is based on the panel data; therefore, the econometric fixed effect panel data model is used for testing the hypothesis. In order to have the comparable data, the data sets for the analysis are chosen from Eurostat. In order to avoid potential distortions and/or very small beta coefficients in quadratic model estimation, the data for GDP were normalised to vary between 0 and 1 , where the smallest value of the whole EU sample is equal to 0 , and the largest value is equal to 1 . At the same time, this facilitates the comparison of the results, as for example 0.5 equals to the average EU level. The pooled EGLS (cross-section weight) method was chosen for the estimation of regression coefficients. The model was validated by the characteristics of the fitted model: $R^{2}$ and Adjusted $R^{2}$; P-values of Fisher and Student tests and residuals. When the $\mathrm{P}$-value is lower than 0.05 , it indicates that this coefficient has a statistically significant explanatory power with the probability of $95 \%$. The main results of the first econometric estimation are presented in Table 4 and analysed in the remaining part of the section. 
Table 3. Country groups and GDP per capita (in PPS)

\begin{tabular}{cccc}
\hline $\begin{array}{c}\text { Country } \\
\text { (developed) }\end{array}$ & $\begin{array}{c}\text { GDP per capita } \\
\text { (in PPS) }\end{array}$ & $\begin{array}{c}\text { Country } \\
\text { (less developed country) }\end{array}$ & $\begin{array}{c}\text { GDP per capita } \\
\text { (in PPS) }\end{array}$ \\
\hline Finland & 16100 & Latvia & 5000 \\
\hline France & 17300 & Lithuania & 5200 \\
\hline United Kingdom & 17700 & Estonia & 5300 \\
\hline Sweden & 19100 & Poland & 6400 \\
\hline Netherlands & 19200 & Slovakia & 7100 \\
\hline Belgium & 19200 & Hungary & 7600 \\
\hline Germany & 19400 & Slovenia & 11100 \\
\hline Denmark & 19600 & Portugal & 11400 \\
\hline Austria & 19900 & Czech Republic & 11500 \\
\hline & & Greece & 12900 \\
\hline & & Spain & 13600 \\
\hline
\end{tabular}

Source: created by authors.

The model was validated by the characteristics of the fitted model. $\mathrm{R}^{2}$ is 0.947 , and Adjusted $\mathrm{R}^{2}$ is 0.944 . $\mathrm{R}^{2}$ is very high due to its estimation specific for pooled data series. The P-value of Student's test provided in the column 'Prob' was used to determine the statistical significance of the estimated coefficients of the proxy variables. F-statistics of the final extended quadratic model is 285.9561 and probability of F-statistics being zero is non-existent. In this case, Durbin-Watson stat is 0.786924 , indicating a substantial serial correlation of the residuals.

The expanded model has five indicators, the parameters of the model are in agreement with the theoretical econometric methodology and economic logic. Summing up the results of the estimation, several conclusions could be made. First, based on mathematical logic, the expanded model may not show the existence of the EKC form because additional variables change the form of a function. Second, the existence of differences between the pollution levels, i.e. the height of $\mathrm{EKC}$, not captured by the factors analysed, in different countries in the model is demonstrated by the differences between a country's intercepts (see data in Table 4). In general, it can be seen in Table 4 that the considered indicators produce a statistically significant effect. The hypothesis has been proved - regression coefficients referring to GDP, Energy consumption have a positive sign, while R\&D and Energy taxes have a negative sign.

In the Table 5 and 6 two groups were estimated separately. By selecting the two groups of countries, we aimed to check if consistent patterns can be found, and if we can conclude that some general tendencies could be distinguished and explained. 
Table 4. Regression parameter estim for the extended model of whole sample

Dependent Variable: GGEKY95_?

Method: Pooled EGLS (Cross-section weights)

Date: 11/01/16 Time: 11:45

Sample: 19952014

Included observations: 20

Cross-sections included: 22

Total pool (balanced) observations: 440

Linear estimation after one-step weighting matrix

White cross-section standard errors \& covariance (no d.f. correction)

\begin{tabular}{|c|c|c|c|c|}
\hline Variable & Coefficient & Std. Error & t-Statistic & Prob. \\
\hline $\mathrm{C}$ & 32.65913 & 2.135344 & 15.29455 & 0.0000 \\
\hline NNGDP3 ? & -33.58998 & 3.660066 & -9.177424 & 0.0000 \\
\hline NNGDP3 $\bar{?}^{\wedge} 2$ & 30.45859 & 3.549525 & 8.581032 & 0.0000 \\
\hline RD ? & -0.014772 & 0.001854 & -7.966668 & 0.0000 \\
\hline ENCONNS? & 23.56765 & 0.423584 & 55.63872 & 0.0000 \\
\hline ENERGTAX & -0.046725 & 0.004276 & -10.92712 & 0.0000 \\
\hline \multicolumn{5}{|l|}{ Fixed Effects (Cross) } \\
\hline LITHUANIA--C & 16.98437 & & & \\
\hline LATVIA--C & 21.00891 & & & \\
\hline ESTONIA--C & -24.84987 & & & \\
\hline GREECE--C & 35.16177 & & & \\
\hline SPAIN--C & 34.50008 & & & \\
\hline PORTUGAL--C & 39.56460 & & & \\
\hline POLAND--C & 10.09621 & & & \\
\hline SLOVENIA--C & 11.08860 & & & \\
\hline SLOVAKIA--C & -9.729859 & & & \\
\hline HUNGARY--C & 14.48681 & & & \\
\hline CZECH_REPUBLIC--C & -23.62292 & & & \\
\hline ITALY--C & 24.31090 & & & \\
\hline DENMARK--C & 10.86147 & & & \\
\hline BELGIUM--C & -46.65139 & & & \\
\hline FRANCE--C & -6.122384 & & & \\
\hline GERMANY--C & -9.914288 & & & \\
\hline NETHERLANDS--C & -30.60862 & & & \\
\hline AUSTRIA--C & 8.757802 & & & \\
\hline SWEDEN--C & -36.63282 & & & \\
\hline UK--C & -1.148085 & & & \\
\hline IRELAND--C & 18.67361 & & & \\
\hline FINLAND--C & -56.21490 & & & \\
\hline \multicolumn{5}{|c|}{ Effects Specification } \\
\hline \multicolumn{5}{|c|}{ Cross-section fixed (dummy variables) } \\
\hline \multicolumn{5}{|c|}{$\begin{array}{ll}\text { Weighted Statistics } \\
\end{array}$} \\
\hline R-squared & \multicolumn{3}{|c|}{ 0.947374 Mean dependent var } & 129.4234 \\
\hline Adjusted R-squared & \multicolumn{3}{|c|}{ 0.944061 S.D. dependent var } & 60.38392 \\
\hline S.E. of regression & \multicolumn{3}{|c|}{ 3.511238 Sum squared resid } & 5091.791 \\
\hline F-statistic & \multicolumn{3}{|c|}{ 285.9561 Durbin-Watson stat } & 0.786924 \\
\hline Prob(F-statistic) & \multicolumn{3}{|c|}{0.000000} & \\
\hline \multicolumn{5}{|c|}{ Unweighted Statistics } \\
\hline R-squared & \multicolumn{3}{|c|}{ 0.903494 Mean dependent var } & 98.06608 \\
\hline Sum squared resid & \multicolumn{3}{|c|}{ 5245.229 Durbin-Watson stat } & 0.606441 \\
\hline
\end{tabular}

Source: made by Eviews. 
Table 5. Regression parameter estimates for the extended model of developed countries

Dependent Variable: GGEKY95 ?

Method: Pooled EGLS (Cross-section weights)

Date: 11/01/16 Time: 11:43

Sample: 19952014

Included observations: 20

Cross-sections included: 9

Total pool (balanced) observations: 180

Linear estimation after one-step weighting matrix

White cross-section standard errors \& covariance (no d.f. correction)

\begin{tabular}{crrrr}
\hline Variable & Coefficient & Std. Error & t-Statistic & Prob. \\
\hline C & 25.97597 & 3.467657 & 7.490928 & 0.0000 \\
NNGDP3_? & -36.89619 & 6.467994 & -5.704426 & 0.0000 \\
NNGDP3_?^2 & 19.82547 & 6.449161 & 3.074117 & 0.0025 \\
RD_? & -0.009492 & 0.001975 & -4.806978 & 0.0000 \\
ENCONS_? & 20.48342 & 0.437939 & 46.77228 & 0.0000 \\
ENERGTAX_? & -0.024334 & 0.009712 & -2.505680 & 0.0132 \\
Fixed Effects (Cross) & & & & \\
DENMARK--C & 21.73176 & & & \\
BELGIUM--C & -23.03218 & & & \\
FRANCE--C & 10.83610 & & & \\
GERMANY--C & 6.935796 & & & \\
NETHERLANDS--C & -8.555090 & & & \\
AUSTRIA--C & 26.58189 & & \\
SWEDEN--C & -17.29304 & & \\
FINLAND--C & -31.93252 & & \\
UK--C & 14.72728 & & \\
\hline \multicolumn{5}{c}{ Effects Specification }
\end{tabular}

Cross-section fixed (dummy variables)

\begin{tabular}{lll}
\hline & Weighted Statistics & \\
\hline R-squared & 0.957704 Mean dependent var & 123.4282 \\
Adjusted R-squared & 0.954392 S.D. dependent var & 63.02371 \\
S.E. of regression & 2.549848 Sum squared resid & 1079.287 \\
F-statistic & 289.1354 Durbin-Watson stat & 0.964610 \\
Prob(F-statistic) & 0.000000 & \\
\hline & Unweighted Statistics & \\
\hline R-squared & 0.934178 Mean dependent var & 94.85392 \\
Sum squared resid & 1094.290Durbin-Watson stat & 0.889704 \\
\hline
\end{tabular}

Source: made by Eviews.

R2 is 0.957704, and Adjusted R2 is 0.954392 are the parametres of the model of developed countries. F-statistics of the final extended quadratic model is 289.1354 and probability of F-statistics being zero is non-existent. In this case, Durbin-Watson stat is 0.964610 , indicating a substantial serial correlation of the residuals. 
Table 6 Regression parameter estimates for the extended model of less developed countries

Dependent Variable: GGEKY95_?

Method: Pooled EGLS (Cross-section weights)

Date: 11/01/16 Time: 12:05

Sample: 19952014

Included observations: 20

Cross-sections included: 13

Total pool (balanced) observations: 260

Linear estimation after one-step weighting matrix

White cross-section standard errors \& covariance (no d.f. correction)

\begin{tabular}{crrrr}
\hline Variable & Coefficient & Std. Error & t-Statistic & Prob. \\
\hline C & 36.58915 & 1.496704 & 24.44649 & 0.0000 \\
NNGDP3_? & -49.09215 & 4.356401 & -11.26897 & 0.0000 \\
NNGDP3_?^2 & 56.96254 & 5.450751 & 10.45040 & 0.0000 \\
RD_? & -0.016278 & 0.004463 & -3.647461 & 0.0003 \\
ENCONS_? & 26.82831 & 0.441897 & 60.71173 & 0.0000 \\
ENERGTAX_? & -0.041586 & 0.004843 & -8.586190 & 0.0000 \\
Fixed Effects (Cross) & & & & \\
LITHUANIA--C & 6.237044 & & & \\
LATVIA--C & 11.85494 & & & \\
ESTONIA--C & -41.12584 & & & \\
GREECE--C & 23.70657 & & & \\
SPAIN--C & 21.68557 & & & \\
PORTUGAL--C & 29.24045 & & & \\
ITALY--C & 10.02865 & & & \\
IRELAND--C & 0.776399 & & & \\
POLAND--C & -0.616355 & & & \\
SLOVENIA--C & -2.772808 & & & \\
SLOVAKIA--C & -23.08905 & & & \\
HUNGARY--C & 3.743309 & & & \\
CZECH_REPUBLIC--C & -39.66889 & & & \\
\hline
\end{tabular}

Effects Specification

Cross-section fixed (dummy variables)

\begin{tabular}{lll}
\hline & Weighted Statistics & \\
\hline R-squared & 0.943435 Mean dependent var & 126.5795 \\
Adjusted R-squared & 0.939462 S.D. dependent var & 56.11432 \\
S.E. of regression & 3.675648 Sum squared resid & 3269.515 \\
F-statistic & 237.4284 Durbin-Watson stat & 0.747492 \\
Prob(F-statistic) & 0.000000 & \\
\hline & Unweighted Statistics & 100.2899 \\
R-squared & 0.901651 Mean dependent var & 0.609162 \\
\hline Sum squared resid & 3401.240 Durbin-Watson stat &
\end{tabular}

Source: made by Eviews.

The third model is valid, as its parameters $\mathrm{R}^{2}$ is 0.943435 , and Adjusted $\mathrm{R}^{2}$ is 0.939462 are the parametres of the model of developed countries. F-statistics of the final extended quadratic model is 237.4284 and probability of F-statistics being zero is non-existent. In this case, Durbin-Watson stat is 0.747492 , indicating a substantial serial correlation of the residuals. 
The existence of differences between pollution levels in different groups of countries not explained by the analysed variables is demonstrated by the remaining differences between a country's intercepts (i.e. the height of EKC). The higher is the intercept of a country, the higher is the unadjusted GHG level. As a general case, countries having a higher development level tend to have a higher EKC (Denmark, Ireland), while less developed countries have a lower EKC (Latvia, Lithuania). The applied EKC estimation method allows evaluating the specific effect of a variable not only on the form but also on the height of EKC (having other effects fixed).

The extended EKC estimation model by the fixed effect panel model for the whole sample and separated groups suggests that the selected indicators (R\&D, Energy consumption, Energy taxes) are the factors relevant for managing the process of climate change as they demonstrate a statistically significant effect (Table 4, 5, 6). The regression coefficients referring to Energy consumption has a positive sign, which means that a higher value of these indicators is associated with a higher level of GHG. The obtained negative signs of R\&D and environmental taxes in the models show that the increase in the values of these variables leads to lower the GHG level. The obtained data allows us to conclude, that the considered countries develop in a similar way and all should analyse various instruments, which could help them to control the level of GHG on their path to economic growth.

Summing up the results from three models several patterns can be derived:

First, EKC functional form can be described evaluating GDP and GDP^ 2 coefficients in Table 4, 5, 6. As they are different this implies different functional forms of EKC in analysed groups of countries. Coefficients indicate that less developed countries are on the flat slope part of standard EKC curve, while more developed countries are on decreasing slope part of standard EKC. This result confirms that region as whole EKC relationship is developing in agreement with standard EKC theories.

Second, analyzing energy efficiency impact it is seen that coefficients of Energy consumption (ECON) are different. Energy consumption variable indicates how much energy is used per inhabitant, i.e. lower indicates more efficient use. The coefficient for energy consumption in the developed countries model was 20.48 and in the less developed countries model 26.83. To estimate if these two coefficients are statistically different standard Z-score statistical test is used, as presented in formula below (Clogg et al. 1995):

$$
z=\left(\beta_{1}-\beta_{2}\right) / \sqrt[2]{s d^{2}\left(\beta_{1}\right)+s d^{2}\left(\beta_{2}\right)}
$$

As calculated Z-score is much higher than critical 99.99\% confidence level, this proves the hypothesis that energy is used less efficiently in less developed countries as was expected.

The following generalities was revealed in this research: first, energy consumption efficiency (as measured by energy used per inhabitant) in more developed European countries are considerably lower than in countries representing group of less developed European countries. The observation holds for the whole considered period, i.e. from 
year 1995 to year 2014. We can claim that observed trends let us reveal one consistent pattern: better developed countries due to technological advance perform much better in energy efficiency area, therefore their energy intensity, as resulting indicator, much better. Here we can assume that behavioural patterns in energy consumption can be characterized by one of the two formulated statements: the first, behavioural patterns are oriented to energy stewardship, either, the second, behavioural patterns are not sequently oriented to energy stewardship. Second, subdivision into country groups indicated that countries in different country development level shows different trend dynamics as indicated by different estimation coefficients for GDP and GDP^2: less developed countries are on increasing EKC trend, while more developed countries are on decreasing trend.

\section{Conclusions}

The estimation of the effects produced on GHG by the economic growth and related various external factors can be viewed as a tool supporting a country's strategic decision. In this paper, the expanded EKC model estimating the relationship between GHG and GDP and some additional factors (e.g. Energy consumption, Energy taxes as well as $\mathrm{R} \& \mathrm{D})$ for the twenty EU countries (including three Baltic States) is tested empirically. The analysis of the expanded model, covering the relevant factors, allows assessing the impact of economic variables on GHG emissions, in order to manage the harmful effect of the economic growth on the environment. In order to test the effects of different factors in the European Union countries, the estimation was made by the fixed effect panel model.

In general, the research confirmed the presence of the inverse U-shaped relationship. Hence, countries having a higher development level tend to be on the higher phase of EKC (Denmark, Ireland), while countries which are less developed are on the lower phase EKC (Latvia, Lithuania). Estonia, the third Baltic country, also belongs to the less developed countries group, but its level of Gross inland energy consumption is substantially higher, than in the other Baltic States, the negative impact of the former factor is partly offset by a negative country's coefficient. Substantial differences in explanatory factors may be related to the specific of its natural resources, coal shale is the main local energy source in Estonia. The empirical expanded EKC model estimation suggests that the analysed factors are relevant for the management of climate change as they demonstrate a statistically significant effect on the dynamics of GHG. The pollution reduction might be expected to occur as a natural by-product of economic development, improving the efficiency, particularly, in energy consumption. Energy taxes are one of the factors affecting market mechanism forces playing out in EKC analysis and can be actively managed by policy makers. The development of cleaner techniques is encouraged by investments in environmental $R \& D$ for which, the sufficient level of economic growth is required. The substantial part of R\&D expenditure in theory might be related to the environmental friendly solutions.

The obtained model coefficient estimates could be directly used as a basis to estimate various scenarios, in order to see the potential future path of the GHG development for a country or region. The obtained results show that the future path of EKC could 
depend on the development level of a specific country. In countries that achieved a higher development level and reached the EKC turning point, the GDP increase would positively impact on the level of GHG. In the Baltic States and Central and Eastern European countries, which have not yet reached the EKC turning point, some additional environmental measures (including changes in the structure of the economy, energy taxes and others) might be used as instruments in the climate change policy adjustment.

The further analysis might be extended into some other areas. Using the proposed technique, other environmental variables could be tested. Another direction of studies may be related to the deeper analysis of the economic shocks with respect to the EKC relationship.

\section{References}

Ajmi, A.; Hammoudeh, S.; Nguyen, D. K.; Sato, J. 2015. On the relationships between $\mathrm{CO}_{2}$ emissions, energy consumption and income: the importance of time variation, Energy Economics 49: 629-638. https://doi.org/10.1016/j.eneco.2015.02.007

Al-mulali, U.; Weng-Wai, C.; Sheau-Ting, L.; Mohammed, A. 2015. Investigating the environmental Kuznets curve (EKC) hypothesis by utilizing the ecological footprint as an indicator of environmental degradation, Ecol. Indic. 48: 315-323.

https://doi.org/10.1016/j.ecolind.2014.08.029

Atici, C. 2009. Carbon emissions in Central and Eastern Europe: environmental Kuznets curve and implications for sustainable development, Sustain. Dev. 17(3): 155-160.

https://doi.org/10.1002/sd.372

Baek, J. 2015. Environmental Kuznets curve for $\mathrm{CO}_{2}$ emissions: the case of Arctic countries, Energy Econ. 50: 13-17. https://doi.org/10.1016/j.eneco.2015.04.010

Baodong, L.; Xiaokun, W. 2011. Economic structure and intensity influence air pollution model, Energy Procedia 5: 803-807. https://doi.org/10.1016/j.egypro.2011.03.141

Boluk, G.; Mert, M. 2014. Fossil \& renewable energy consumption, GHGs (greenhouse gases) and economic growth: evidence from a panel of EU countries, Energy 74(1): 439-446.

https://doi.org/10.1016/j.energy.2014.07.008

Clogg, C; Petkova, E.; Haritou, A. 1995. Statistical methods for comparing regression coefficients between models author(s), The American Journal of Sociology 100(5): 1261-1293.

https://doi.org/10.1086/230638

Esteve, V.; Tamarit, C. 2012. Is there an environmental Kuznets curve for Spain? Fresh evidence from old data, Economic Modelling 29(6): 2696-2703.

https://doi.org/10.1016/j.econmod.2012.08.016

Europe 2020. 2010. A strategy for smart, sustainable and inclusive growth [online], [cited 17 September 2016]. Available from Internet: http://ec.europa.eu/europe2020/index_en.htm

Eurostat. 2016 [online], [cited 10 February 2016]. Available from Internet: http://epp.eurostat. ec.europa.eu/

Fujii, H.; Managi, S. 2013. Which industry is greener? An empirical study of nine industries in OECD countries, Energy Policy 57: 381-388. https://doi.org/10.1016/j.enpol.2013.02.011

Ginevičius, R.; Lapinskienè, G.; Peleckis, K. 2017. The evolution of the environmental Kuznets curve concept: the review of the research, Panoeconomicus 64(1): 93-112.

https://doi.org/10.2298/PAN150423012G

Grossman, G. M.; Krueger, A. B. 1991. Environmental impact of a North American free trade agreement. Working Paper 3194. Cambridge, MA: National Bureau of Economic Research. https://doi.org/10.3386/w3914 
Grossman, G. M.; Krueger, A. B. 1995. Economic growth and the environment, Quarterly Journal of Economics 110: 353-377. https://doi.org/10.2307/2118443

He, J., Wang, H. 2012. Economic structure, development policy and environmental quality: an empirical analysis of environmental Kuznets curves with Chinese municipal data, Ecological Economics 76: 49-59. https://doi.org/10.1016/j.ecolecon.2012.01.014

Holtz-Eakin, D.; Selden, T. M. 1995. Stoking the fires? $\mathrm{CO}_{2}$ emissions and economic growth, Journal of Public Economics 57: 85-101. https://doi.org/10.1016/0047-2727(94)01449-X

Iwata, H.; Okada, K.; Samreth, S. 2011. A note on the environmental Kuznets curve for $\mathrm{CO}_{2}$ : a pooled mean group approach, Applied Energy 88: 1986-1996.

https://doi.org/10.1016/j.apenergy.2010.11.005

Kasman, A.; Duman, Y. S. 2015. $\mathrm{CO}_{2}$ emissions, economic growth, energy consumption, trade and urbanization in new EU member and candidate countries: a panel data analysis, Econ. Model 44: 97-103. https://doi.org/10.1016/j.econmod.2014.10.022

Lapinskienè, G.; Tvaronavičienè, M.; Vaitkus, P. 2014. The emissions of greenhouse gases and economic growth - the evidence of the presence of the environmental Kuznets curve in the European Union countries, Technological and Economic Development of Economy 20(1): 65-78. https://doi.org/10.3846/20294913.2014.881434

Lapinskienè, G.; Tvaronavičienè, M.; Vaitkus, P. 2013. Analysis of the validity of environmental Kuznets curve for the Baltic States, Environmental and Climate Technologies 12: 41-46.

https://doi.org/10.2478/rtuect-2013-0015

Lapinskienè, G; Peleckis, K.; Nedelko, Z. 2017. Testing environmental Kuznets curve hypothesis: the role of enterprise's sustainability and other factors on GHG in European countries, Journal of Business Economics and Management 18(1): 54-67.

https://doi.org/10.3846/16111699.2016.1249401

Liao, H.; Cao, H. 2013. How does carbon dioxide emission change with the economic development? Statistical experiences from 132 countries, Global Environmental Change 5: 1073-1082. https://doi.org/10.1016/j.gloenvcha.2013.06.006

Lin, C. Y.; Liscow, Z. D. 2013. Endogeneity in the environmental Kuznets curve: an instrumental variables approach, American Journal of Agricultural Economics 95(2): 268-274.

https://doi.org/10.1093/ajae/aas050

Lopez-Menendez, A. J.; Perez, R.; Moreno, B. 2014. Environmental costs and renewable energy: re-visiting the environmental Kuznets curve, Environmental Management 145: 368-373.

https://doi.org/10.1016/j.jenvman.2014.07.017

Marrero, G. A. 2010. Greenhouse gases emissions, growth and the energy mix in Europe, Energy Econ. 32(6): 1356-1363. https://doi.org/10.1016/j.eneco.2010.09.007

Meadows, D. H.; Meadows, D. L.; Randers, J.; Behrens, W. 1972. Limits to growth: a report for the Club of Rome's Project on the redicament of mankind. New York: Universe Books.

Onafowora, O.; Owoye, O. 2014. Bounds testing approach to analysis of the environment Kuznets curve hypothesis, Energy Economics 44: 47-62. https://doi.org/10.1016/j.eneco.2014.03.025

Ozturk, A.; Acaravci, A. 2010. The causal relationship between energy consumption and GDP in Albania, Bulgaria, Hungary and Romania: evidence from ARDL bound testing approach, Appl. Energy 87(6): 1938-1943. https://doi.org/10.1016/j.apenergy.2009.10.010

Potocan, V.; Nedelko, Z.; Peleckienè, V.; Peleckis, K. 2016. Values, environmental concern and economic concern as predictors of enterprise environmental responsiveness, Journal of Business Economics and Management 17(5): 685-700. https://doi.org/10.3846/16111699.2016.1202315

Randers, J. 2012. A global forecast for the next forty years 2052. Vermont: Chelsea green publishing white river junction. 
Selden, T. M.; Song, D. 1994. Environmental quality and development: is there a Kuznets curve for air pollution emissions, Environmental Economics and Management 27: 147-162.

https://doi.org/10.1006/jeem.1994.1031

Shafik, N.; Bandyopadhyay, S. 1992. Economic growth and environment quality: time series and cross-country evidence. Background Paper for the World Development Report. The World Bank, Washington DC.

Shahbaz, M.; Nasreen, S.; Abbas, F.; Anis, O. 2015. Does foreign direct investment impede environmental quality in high-, middle-, and low-income countries?, Energy Econ. 51: 275-287. https://doi.org/10.1016/j.eneco.2015.06.014

Wang, S.; Zhou, D. Q.; Zhou, P.; Wang, Q. 2011. $\mathrm{CO}_{2}$ emissions, energy consumption and economic growth in China: a panel data analysis, Energy Policy 39: 4870-4875.

https://doi.org/10.1016/j.enpol.2011.06.032

Giedrè LAPINSKIENE். Lecturer, PhD in Social Sciences (economics) at the Department of Business Technologies and Entrepreneurship, VGTU. Research interests: sustainable development, environmental economics, green business.

Kęstutis PELECKIS. Professor, $\mathrm{PhD}$ in Social Sciences (economics) at the Department of Business Technologies and Entrepreneurship, VGTU. The author of more than 100 publications. Research interests: economic growth, sustainable development, increase in the efficiency of business meetings and negotiations.

Neringa SLAVINSKAITE். Lecturer, PhD in Social Sciences (economics) at the Department of Logistics and Transport Management, VGTU. Research interests: fiscal decentralization, economic growth, finance. 